<原 著 $>$

\title{
胃静脈瘤の血行動態一PTP による検討
}

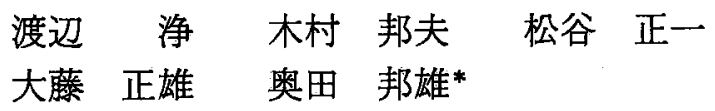

要 旨：胃静脈瘤は食道静脈瘤に比し出血頻度が低いとされているが，その血行動態の検討は 充分にはなされていない，そこで胃静脈瘤の血行動熊を経皮経肝門脈造影 (PTP) により检討 し, 食道静脈瘤との血行動態の差異や門脈圧, 肝性脑症との関連について言及した. 230例の食 道胃静脈癉症例に対し，内視鏡と PTP を施行し以下の結果を得た。（1）胃静脈瘤は $57 \%$ 亿存在 し高度になるにつれ短胃静脈，後胃静脈支配型が増える。（2）胃静脈鹰高度例では胃腎短絡路 が高率に存在する.（3）胃堅短絡路を有する群は有しない群に比し，門脈正は有意低低い。（4） 高度胃静脈瘤を有する群は，反復性肝性脑症を起こす頻度が高い。

以上胃静脈瘤は食道静脈瘤とは異なった血行動態及び臨床病態を有することを明らかにし た.

索引用語： 胃静脈瘤 PTP 胃腎短絡路 反復性肝性脳症

\section{緒，言}

従来門脈圧え進症に伴う胃静脈瘤は，食道静脈瘤に 比し出血頻度が低いとされているが',2), その門脈 X線 像による検討も充分にはなされていない，著者らは， 内視鏡的汇確認された胃静脈瘤の血行動態を経皮経肝 聞脈造影により検討したところ，食道静脈瘤との血行 動態の差異や特徵的な所見を得た。また胃静脈瘤と門 脈压, 反復性肝性脳症などとの関連について子興味あ る結果を得たので報告する。

\section{対象及び研究方法}

対象：昭和55年 9 月から昭和60年 4 月まで千葉大学 第一内科及び関連施設で, 食道胃内視鏡と経皮経肝門 脈造影(以下 PTP)を施行した230例の食道胃静脈瘤症 例を対象とした。疾患内訳は，腹腔鏡及び肝生検で確 認された肝硬変201例（ちち5 cm 以下の小肝癌合併例 32例含含它)，特発性門脈圧六進症20例，原発性胆汁性 䀒硬変 4 例，その他 5 例であった．尚，門脈圧六進症 に対する手術既応例は検討対象から除外した.

研究方法

内視鏡的検討：食道静脈瘤(以下 EV)は日本門脈圧 穴進症研究会に上る食道静脈瘤内視鏡所見記載基準3) に従い，その形状を $\mathrm{F}_{1} \sim \mathrm{F}_{3}$ に分類した。胃静脈瘤（以

\footnotetext{
* 千葉大学第 1 内科
}

＜受付日61年12月22日 $>$
下 GV) は安元ら゙のの X線分類を応用し，次のごとく (+)〜(H) K分類した (Fig. 1).

GV $(+)$ : 胃噴門部周囲に軽度の静脈瘤を認めるも の.

GV (H)：噴門部周聿から穹隆部に及ぶ蛇行する静 脈瘤を認めるるの.

GV (卅)：腫瘤状を呈するるの，広がりは問わない。 $\mathrm{GV}($ ( )：胃静脈瘤を認めないるの.

PTP による検討：PTP は超音波映像下穿刺法 ${ }^{5,6}$ に より行ない，脾門部脾静脈造影々上腸間膜静脈造影を 基本とした。

食道胃静脈瘤への流入血行路(遠肝性の左右胃静脈, 後胃静脈及び短胃静脈) を明らかにし，これらの径の 計測から支配血行路を明らかにした。尚，PTPKよる 短胃静脈（群）とは，脾門部脾静脈や脾内分枝から上

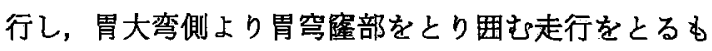
のとし，これとは別に脾静脈中央部付近から上行し， 直接胃噴門部方向に至る血行を後胃静脈とした。この 後胃静脈とは, 解剖学的に統一された名称ではなく， 噴門食道静脈, 副左胃静脈, 無名静脈などとも呼ばれ, 胃の後面小弯より出て脾静脈に注ぐが，門六症に際し ては左右胃静脈，短胃静脈之並んで大きな側副路を形 成するすのである7

また，これらの静脈瘤流入血行路から左腎静脈へ短 絡する，いわゆる胃腎短絡路（以下 G-R shunt）の有 


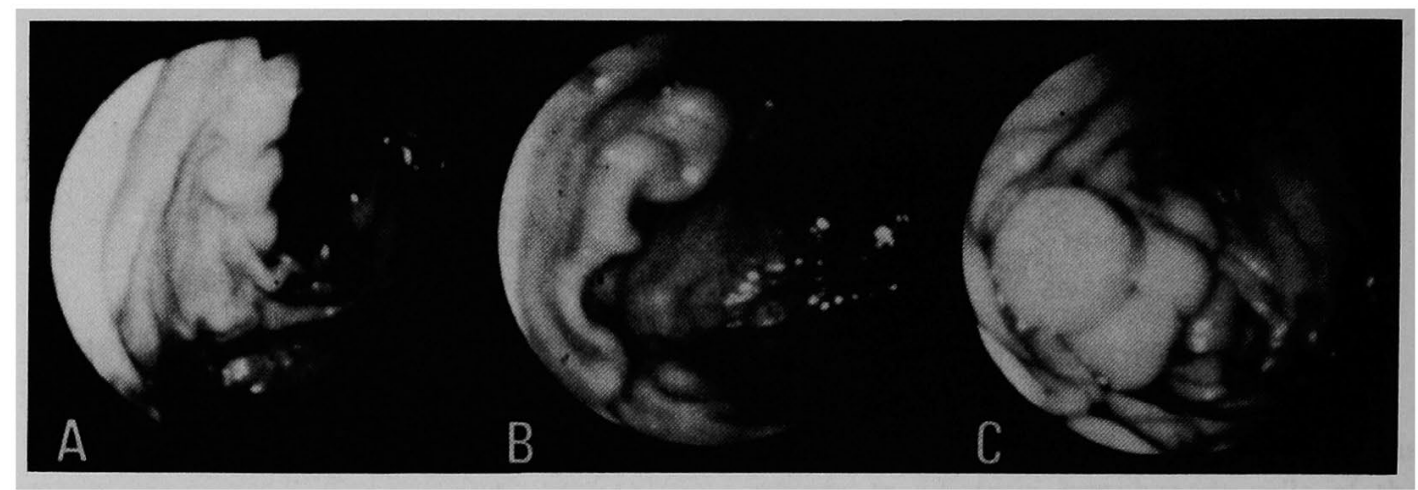

Fig. 1 Endoscopic features of three grades of gastric varices. A. GV $(+)$ : slightly elevated gastric varices surrounding the gastric cardia. B. GV (H): moderately elevated gatric varices locating from the gastric cardia to the posterior wall of the fundus. C. GV (卅) : markedly elevated gastric varices like a gastric tumor.

無とその程度も加えて検討した，更に，静脈瘤流入血 管と脾静脈逆流現象及び肝内造影度の関係を, 造影所 見から分類し検討した。門脈各部位における血流方向 からみた血行動態も検討した.

内視鏡所見と PTP 所見の比較検討：内視鏡に括け る食道静脈瘤と胃静脈瘤の優位性とPTP 所見につき 検討した。

反復性肝性脳症との関係：高アンモニア血症に伴う 反復性肝性脳症と, $\mathrm{EV}$ と GV の優位性及び聞脈血行 動態の 3 者の関連につき検討した.

\section{成 䋶}

1. 内視鏡に上る食道胃静脈瘤所見

$\mathrm{EV}, \mathrm{GV}$ を研究方法の項で述べた判定基準に基つき 検討したところ, 以下のごとく両者の関係は 5 型に分 類された。

EV 群：食道静脈瘫単独群

$\mathrm{EV}>\mathrm{GV}$ 群 : 食道静脈瘤優位群

$\mathrm{EV} \fallingdotseq \mathrm{GV}$ 群 : 食道胃静脈瘤同等群

$\mathrm{EV}<\mathrm{GV}$ 群：胃静脈瘤優位群

$\mathrm{GV}$ 群：胃静眽瘤単独群

(尚, $\mathrm{EV}$ と GV の関係は, $F_{1}$ と GV (+), $F_{2}$ と GV (H), $F_{3}$ と GV (卅) を同程度と判定した.)

このちち EV 群は $99 / 230(43.0 \%), \mathrm{EV}>\mathrm{GV}$ 群は 98/230(42.6\%), $\mathrm{EV} \fallingdotseq \mathrm{GV}$ 群は10/230(4.3\%), EV< $\mathrm{GV}$ 群は15/230(6.5\%), GV 群は8/230(3.5\%)であっ た.

2.PTPによる食道胃静脈瘤造影所見の検討

（1）食道胃静脈瘤支配血行路 (Fig. 2, Table 1)
PTPによる脾静脈脾門部からの造影で, 左右胃静 脈，後胃静脈，短胃静脈が食道胃静脈瘤を形成する血 行路として貢献している事が明らかとなった。これら の静脈瘤支配血行路は大きく 3 つの型に大別された (Fig. 2).つまり，主として左胃静脈群(右胃静脈を含 む) に支配されるものを右型 $(R>L)$, 短胃静脈群, 後 胃静脈に支配されるものを左型 $(R<L)$, 両者よりほ注 同等に支配されるものを均等型 $(\mathrm{R} \fallingdotseq \mathrm{L})$ とした。

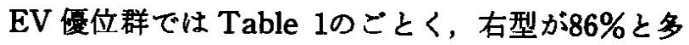
数を占めるが, GV 優位群及び GV 群では逆に左型为 それぞれ53\%，50\%を増加する。このことより GVの 血行には, 短胃静脈及び後胃静脈が優位に支配してい ることが明らかになった。 また EV 群では83\%が右型 を量することからす，EVの血行には左胃静脈が深く 関与することが明らかである。

（2）食道胃静脈瘤之胃腎短絡路（Fig. 3, Table 2)

PTPにより認められた胃督短絡路 (G-R Shunt と略 す）の程度を下記のこととく(ー)〜（卅）の 4 段階に分 類し検討した。

胃腎短絡路は, 遠肝性の胃静脈群（左右胃静脈，後 胃静脈, 短胃静脈) が発達し, 胃噴門部から生理的に 存在する下横隔静脈と左副腎静脈の交通枝を下行し, 側副路として発達したものを呼ぶ7,8).

左腎静脈へ注ぐ左副腎静脈の径により(一)〜(卅) に分類し， $5 \mathrm{~mm}$ 以下を $(+), 5 \mathrm{~mm}$ 以上 $10 \mathrm{~mm}$ 未満を (H)，10mm 以上を(卅) とした。尚，(十）は脾門部 造影では造影されず，選択造影にて初めて出現する場 合もあった (Fig. 3). 


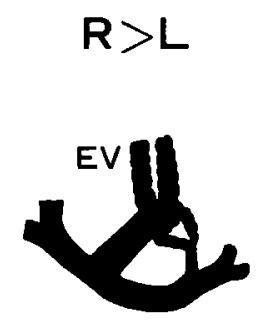

$$
\mathrm{R} \doteqdot \mathrm{L}
$$

$\mathbf{R}<\mathrm{L}$
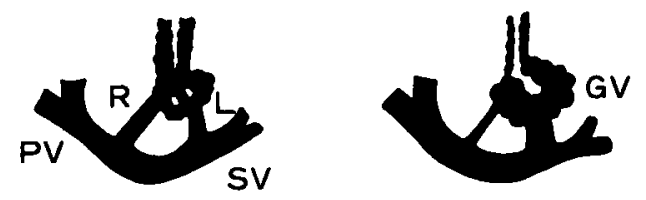
$\mathbf{R}$ : left or right gastric vein
PV : portal vein
SV : splenic vein
$L$ : posterior and/or short gastric vein
EV : esophageal varices
GV : gastric varices

Fig. 2 Types of variceal supply classified by portography (PTP) (Study on 230 patients).

Table 1 Relationship between endoscopic appearance and PTP finding of gastroesophageal varices.

\begin{tabular}{|c|c|c|c|c|}
\hline \multirow{2}{*}{$\begin{array}{l}\text { Types of } \\
\text { varices }\end{array}$} & \multicolumn{4}{|c|}{ Types of variceal supply (PTP) } \\
\hline & $R>L$ & $\mathrm{R} \leftrightharpoons \mathrm{L}$ & $\mathrm{R}<\mathrm{L}$ & Total \\
\hline EV & $\begin{array}{c}83 \\
(83 \%)\end{array}$ & $\begin{array}{c}\mathbf{5} \\
(\mathbf{5} \%)\end{array}$ & $(11 \%)$ & 99 \\
\hline $\mathrm{EV}>\mathrm{GV}$ & $\begin{array}{c}84 \\
(86 \%)\end{array}$ & $\begin{array}{c}8 \\
(8 \%)\end{array}$ & $\begin{array}{c}6 \\
(6 \%)\end{array}$ & 98 \\
\hline $\mathrm{EV} \fallingdotseq \mathrm{GV}$ & $\begin{array}{c}5 \\
(50 \%)\end{array}$ & $\begin{array}{c}3 \\
(30 \%)\end{array}$ & $\stackrel{2}{2}$ & 10 \\
\hline $\mathrm{EV}<\mathrm{GV}$ & $\begin{array}{c}5 \\
(33 \%)\end{array}$ & $\stackrel{2}{2}$ & $\begin{array}{c}8 \\
(53 \%)\end{array}$ & 15 \\
\hline GV & $\begin{array}{c}2 \\
(25 \%)\end{array}$ & $\stackrel{2}{2}$ & $\begin{array}{c}4 \\
(50 \%)\end{array}$ & 8 \\
\hline
\end{tabular}

EV : esophageal varices $\mathrm{R}$ : left or right gastric vein GV : gastric varices $\mathrm{L}$ : posterior and/or short gastric veins

Table 2のごとく, G-R Shunt は EV 単独群で17\%, $\mathrm{EV}$ 優位群で21\%と低率であり，その程度も(十)が 74\%を占めた。しかし GV 優位群及び GV 単独群では それぞれ80\%，100\%と高率であり，その程度す（H） 一(卅)が87\%を占め, G-R Shunt の発達が著明である.

（3）食道胃静脈瘤と門脈压（Table 3)

PTPにより門脈本幹で測定した門脈圧と，食道胃静 脈瘤及び胃腎短絡路との関係につき検討した. EV 単 独群では $326 \pm 66 \mathrm{mmH}_{2} \mathrm{O}$, 胃静脈瘤を有する例では胃 静脈瘤の発達とともに門脈圧の低下がみられ，EV 優 位群では $340 \pm 65 \mathrm{mmH}_{2} \mathrm{O}$, 同等群 $337 \pm 63 \mathrm{mmH}_{2} \mathrm{O}$, $\mathrm{GV}$ 優位群 $302 \pm 75 \mathrm{mmH}_{2} \mathrm{O}, \mathrm{GV}$ 単独群 $240 \pm 37 \mathrm{mmH}_{2}$ Oであった. EV 単独群と GV 単独群との間には危険
Table 2 Relationship between types of gastroesophageal varices and gastro-renal shunt.

\begin{tabular}{lc|c|c|c|c|c}
\hline \multirow{2}{*}{ Types of varices } & \multicolumn{4}{|c|}{ G-R shunt } & \multirow{2}{*}{$\begin{array}{c}\text { Frequency of } \\
\text { G.R shunt }\end{array}$} \\
\cline { 3 - 7 } & - & + & + & H & \\
\hline $\mathrm{EV}$ & $\mathrm{n}=99$ & 82 & 14 & 2 & 1 & $17 \%$ \\
\hline $\mathrm{EV}>\mathrm{GV}$ & $\mathbf{n}=98$ & 77 & 14 & 4 & 3 & $21 \%$ \\
\hline $\mathrm{EV} \leftrightharpoons \mathrm{GV}$ & $\mathrm{n}=10$ & 4 & 1 & 1 & 4 & $60 \%$ \\
\hline $\mathrm{EV}<\mathrm{GV}$ & $\mathrm{n}=15$ & 3 & 0 & 4 & 8 & $80 \%$ \\
\hline $\mathrm{GV}$ & $\mathrm{n}=8$ & 0 & 0 & 1 & 7 & $100 \%$ \\
\hline \multicolumn{5}{c}{ G-R shunt : gastro-renal shunt }
\end{tabular}

Table 3 Relationship between types of gastroesophageal varices and portal venous pressure (PVP).

\begin{tabular}{|c|c|c|c|}
\hline \multicolumn{2}{|c|}{ Types of varices } & \multicolumn{2}{|c|}{ PVP (Mean \pm SD $\left.\mathrm{mmH}_{2} \mathrm{O}\right)$} \\
\hline EV & $\mathbf{n}=99$ & $326 \pm 66^{* *}$ & \\
\hline $\mathrm{EV}>\mathrm{GV}$ & $\mathrm{n}=98$ & $340 \pm 65$ & $\begin{array}{c}\text { G-R shunt } \\
n=82\end{array}$ \\
\hline $\mathrm{EV} \leftrightharpoons \mathrm{GV}$ & $\mathrm{n}=10$ & $337 \pm 63$ & $339 \pm 66^{*}$ \\
\hline $\mathrm{EV}<\mathrm{GV}$ & $\mathrm{n}=15$ & $302 \pm 75$ & $\begin{array}{c}\text { G-R shunt } \\
n=47\end{array}$ \\
\hline GV & $\mathrm{n}=8$ & $240 \pm 37^{* *}$ & $311 \pm 73^{*}$ \\
\hline
\end{tabular}

率 $1 \%$ 以下で有意差を認め, EV 優位群と GV 単独群 との間にも有意差を認めた $(\mathrm{p}<0.01)$.

さらに, 胃静脈瘤を有する群について G-R Shunt の 有無により門脈圧を比較すると， G-R Shunt 無の群で は339 $666 \mathrm{mmH}_{2} \mathrm{O}$, 有の群では $311 \pm 73 \mathrm{mmH}_{2} \mathrm{O}$ と両 

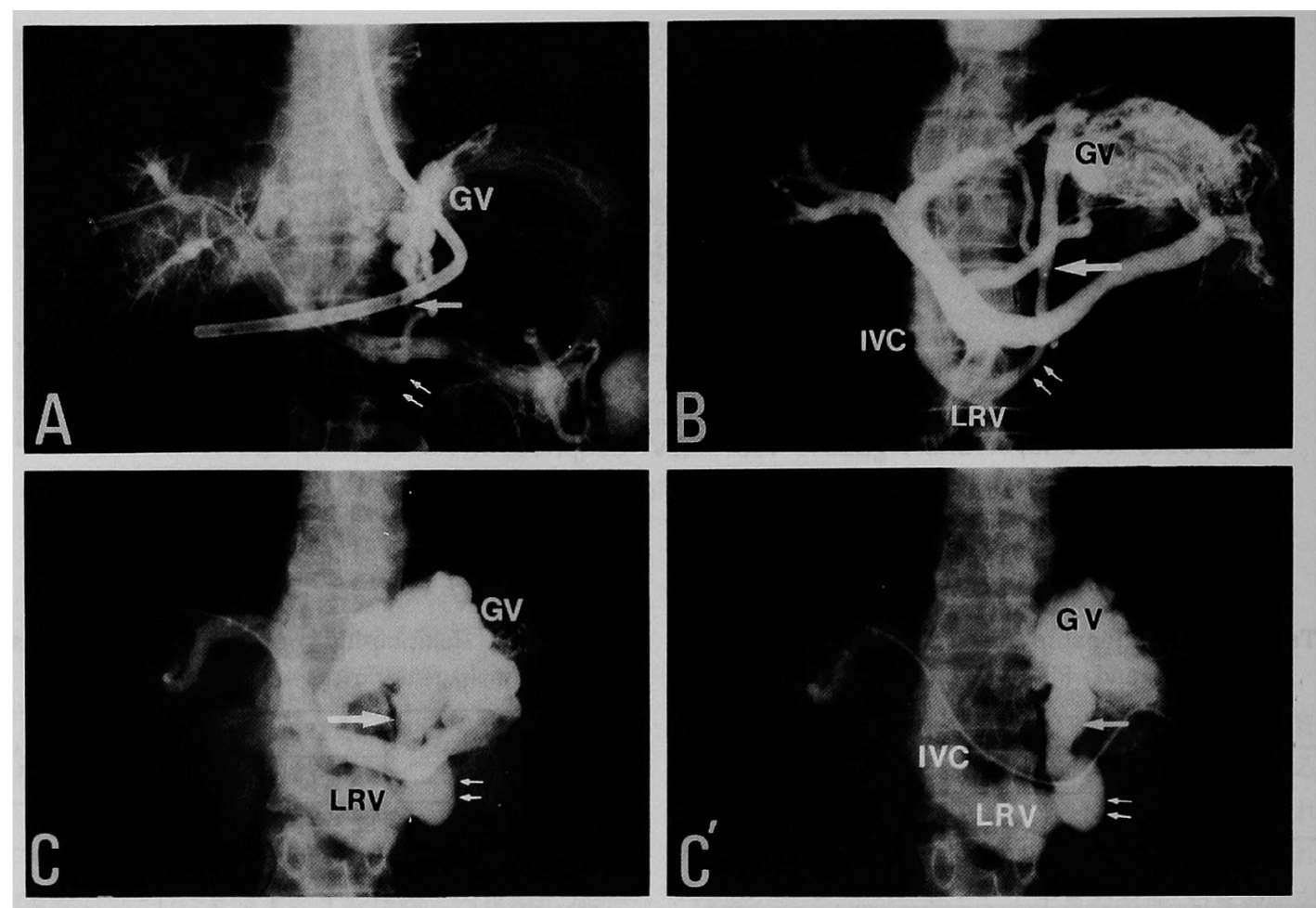

Fig. 3 Portographic patterns of three grades of gastro-renal shunt (G-R shunt) demonstrated by percutaneous transhepatic portography. A. G-R shunt $(+)$, B. G-R shunt (H), C. G-R shunt (H), C'. late phase of "C" (GV : gastric varices, IVC : inferior vena cava, LRV : left renal vein, $\diamond:$ inferior phrenic vein, $\leftleftarrows$ : left adrenal vein)

Table 4 Relationship between gastro-renal shunt and portal venous pressure (PVP).

\begin{tabular}{|c|c|c|c|c|c|}
\hline & & \multicolumn{4}{|c|}{ Gastro-renal shunt } \\
\hline & & - & + & H & 世 \\
\hline \multirow{2}{*}{ 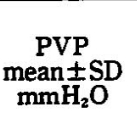 } & $\mathrm{GV}(+)$ & $\begin{array}{r}n=84 \\
339 \pm 66\end{array}$ & $\begin{array}{r}n=15 \\
343 \pm 65\end{array}$ & $\begin{array}{r}n=10 \\
345 \pm 56\end{array}$ & $\begin{array}{r}n=22 \\
277 \pm 67\end{array}$ \\
\hline & $\mathrm{GV}(-)$ & $\begin{array}{r}n=82 \\
326 \pm 66\end{array}$ & & $\begin{array}{r}n=17 \\
324 \pm 59\end{array}$ & \\
\hline
\end{tabular}

GV : gastric varices

群の間に有意差を認めた（ $\mathrm{p}<0.05$ : normal distribution test).

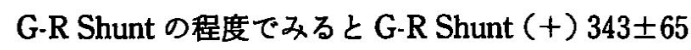
$\mathrm{mmH}_{2} \mathrm{O}$, (H) $345 \pm 56 \mathrm{mmH}_{2} \mathrm{O}$, (H) $277 \pm 67 \mathrm{mmH}_{2} \mathrm{O}$ であり（十）及び（H）の群と（卅）の群の間に有意 差を認めた。 EV 単独群でみると， G-R Shunt の有無 で門脈圧に有意差を認めなかった（Table 4).

次に, G.R Shunt と比較するため, 食道胃静脈瘤を
Table 5 Relationship between spleno-renal shunt and portal venous pressure (PVP).

\begin{tabular}{lc|c|c|c}
\hline \multirow{2}{*}{} & & \multicolumn{3}{|c}{ Spleno-renal shunt } \\
\cline { 3 - 5 } & + & + & H \\
\hline Frequency & $\mathrm{n}=230$ & $(5.2 \%)$ & $(2.2 \%)$ & $(1.7 \%)$ \\
\hline $\begin{array}{l}\text { PVP } \\
\text { mean } \pm \text { SD }\end{array}$ & $\mathrm{mmH}_{2} \mathrm{O}$ & $328 \pm 67$ & $337 \pm 32$ & $313 \pm 111$ \\
\hline
\end{tabular}

有する症例の脾腎短絡路（S-R Shunt と略す）の頻度 と門脈王を検討した. S-R Shunt の程度を左腎静脈へ 注ぐ血行路の径により分類し, $5 \mathrm{~mm}$ 末満を(十), $5 \mathrm{~mm}$ 以上 $10 \mathrm{~mm}$ 末满を (H), $10 \mathrm{~mm}$ 以上を(\#) とした。 Table 5のごとく, 頻度は S-R Shunt (+) 5.2\%, (H) $2.2 \%$ （卅） $1.7 \%$ と低く, 門脈圧多 S-R Shunt (+) $328 \pm 67 \mathrm{mmH}_{2} \mathrm{O}$, (H) $337 \pm 32 \mathrm{mmH}_{2} \mathrm{O}$ ，(卅） $313 \pm$ $111 \mathrm{mmH}_{2} \mathrm{O}$ と 3 群間に有意差を認めなかった。 


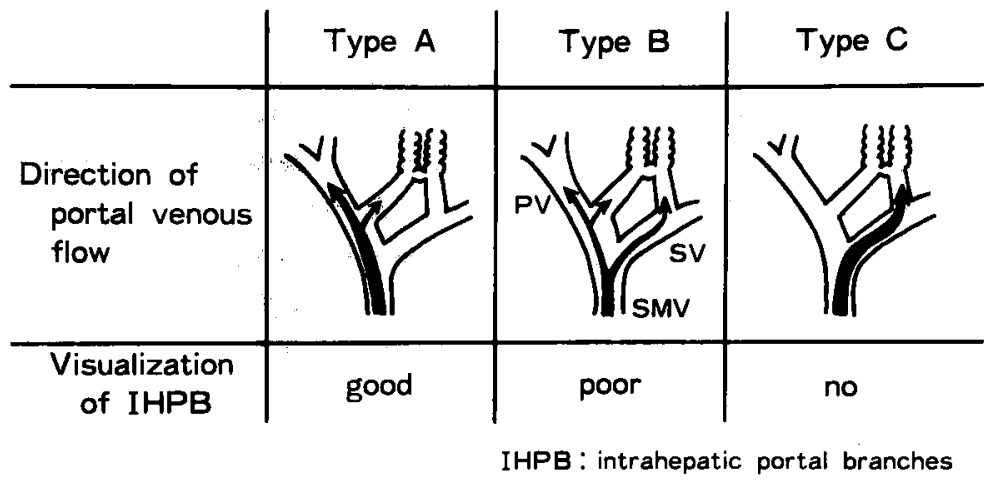

Fig. 4 Schematic presentation of types of portal hemodynamics.

Table 6 Relationship between types of gastroesophageal varices and types of portal hemodynamics.

\begin{tabular}{|c|c|c|c|}
\hline \multirow{2}{*}{ Types of varices } & \multicolumn{3}{|c|}{ Types of portal hemodynamics } \\
\hline & A & B & $\mathrm{C}$ \\
\hline EV & $\begin{array}{c}95 \\
(96 \%)\end{array}$ & $(\stackrel{3}{3 \%})$ & $\left(\frac{1}{1 \%}\right)$ \\
\hline $\mathrm{EV}>\mathrm{GV}$ & $\begin{array}{c}89 \\
(90 \%)\end{array}$ & $(10 \%)$ & $\left(\begin{array}{c}0 \\
0 \%\end{array}\right)$ \\
\hline $\mathrm{EV} \leftrightharpoons \mathrm{GV}$ & $\begin{array}{c}6 \\
(60 \%)\end{array}$ & $\stackrel{4}{(40 \%)}$ & $\left(\begin{array}{c}0 \\
0 \%\end{array}\right)$ \\
\hline EV $<$ GV & $\begin{array}{c}10 \\
(67 \%)\end{array}$ & $\begin{array}{c}5 \\
(33 \%)\end{array}$ & $\left(\begin{array}{c}0 \\
0 \%\end{array}\right)$ \\
\hline GV & $(12 \%)$ & $\begin{array}{c}5 \\
(63 \%)\end{array}$ & $\begin{array}{c}2 \\
(25 \%)\end{array}$ \\
\hline
\end{tabular}

（4）食道胃静脈瘤と血行動態（Fig. 4, Table 6) 上腸間膜静脈 (以下 SMV) からの血流方向と，食道 胃静脈瘤との関連について検討した. Fig. 4のごとく， SMV の血流がすべて門脈本幹に流入し，肝内造影度 良好なものを Type A, 一部脾静脈に逆流し肝内造影 度が低下するるのを Type B，すべて脾静脈に逆流し 肝内は造影されないるのを Type C として検討した。 Table 6に示すごとく,EV 単独群及び EV 優位群では それぞれ96\%，90\%が Type Aであり，GVが発達す るにつれ Type B が増加し， GV 優位群では $33 \%, G V$ 単独群では63\%を占めた, 又, GV 単独群では Type C が25\%を占わた。

3.（1）胃静脈瘤と反復性肝性脳症（Table 7)

今回検討した食道胃静脈瘤症例230例のうち，典型的 な反復性肝性脳症は12例に認められ，うち5例 (41.7\%)に高度の胃静脈瘤を認めた。 そこで，胃静脈
Table 7 Relationship between types of gastroesophageal varices and frequency of portal systemic encephalopathy (PSE).

\begin{tabular}{ll|c}
\hline \multicolumn{2}{c|}{ Types of varices } & Frequency of PSE \\
\hline $\mathrm{EV}$ & $\mathrm{n}=99$ & $3(3.0 \%)$ \\
\hline $\mathrm{EV}>\mathrm{GV}$ & $\mathrm{n}=98$ & $4(4.1 \%)$ \\
\hline $\mathrm{EV} \leqq \mathrm{GV}$ & $\mathrm{n}=25$ & $3(12.0 \%)$ \\
\hline $\mathrm{GV}$ & $\mathrm{n}=8$ & $2(25.0 \%)$ \\
\hline \multicolumn{2}{r}{} & ${ }^{*} \mathrm{p}<0.01\left(x^{2}\right.$ test $)$
\end{tabular}

Table 8 Relationship between types of portal hemodynamics and frequency of portal systemic encephalopathy (PSE).

\begin{tabular}{|c|c|c|}
\hline \multicolumn{2}{|c|}{$\begin{array}{l}\text { Types of portal } \\
\text { hemodynamics }\end{array}$} & \multirow{2}{*}{$\begin{array}{l}\text { Frequency of PSE } \\
2(1.0 \%)\end{array}$} \\
\hline Type A & $\mathrm{n}=\mathbf{2 0 1}$ & \\
\hline Type B & $\mathrm{n}=26$ & $8(30.8 \%)$ \\
\hline Type C & $n=3$ & $2(66.7 \%)$ \\
\hline
\end{tabular}

瘤と反復性肝性脳症の関連をみると，Table 7に示す ごとく，EV 単独群及び EV 優位群での反復性肝性脳 症の頻度は，それぞれ 3\%，4\%と稀であるが, GV 優 位群及び GV 単独群では，それぞれ $12 \% ， 25 \%$ と高率 であり, EV 単独群と GV 単独群の間には有意差を認 めた $(p<0.01)$. また EV 単独群と EV 優位群を合わ せた群と，GV 優位群及び GV 単独群を合わせた群の 間にも，反復性肝性脳症の頻度に打いて有意差を認め た ( $<<0.05: \chi^{2}$ test).

（2）反復性肝性脳症之血行動態（Table 8) 反復性肝性脳症をSMV からの血行動態でみると, 
SMV の血流がすべて門脈本幹に流入する Type Aで は $1 \%$ と低率であるか，血流が一部脾静脈に逆流する Type Bでは30.8\%，血流がすべて脾静脈に流入する Type Cでは, 66.7\%と高率であった.

次にこの12例の反復性肝性脑症と大短絡路の関連を みると，著明に発達した G-R Shunt が脳症の原因とな るものは5/12 (41.7\%), S-R Shunt が関与するもの $2 / 12(16.7 \%)$ ，著明な傍食道静脈が関与するるの 2/12（16.7\%）であった。その他，脐傍静脈発達著明 な例や，食道静脈瘤以外の巨大短絡路を有さない例も あった.

\section{考 察}

従来, 食道静脈瘤はその破綻出血が高率なことから， 門六症の合併症として臨床的に重視されている1)が, 胃静脈瘤に関してはその研究報告も少なく $4,10,11)$, 血行 動熊についての論文は全く認められない，また，胃静 脈瘤からの出血は比較的少ない2)とされるが，その理 由は明確にはされていない，今回我々は，内視鏡的に 胃静脈瘤を認めた症例の PTP 所見を中心に分析し， 食道静脈瘤症例と対比しながら門脈造影からみたその 血行動態を検討した.

今回の門六症例における, 食道胃静脈瘤症例の内視 鏡的検討によれば，胃静脈瘤の頻度は $57 \%$ で従来の報 告2,4) とほぼ一致し，決してその頻度は少なくない，し かし胃静脈瘤がこの様に高率に存在するにもかかわら ず, 胃静脈瘤からの出血は食道静脈瘤破糘出血に比し 少ない，胃静脈瘤を多数例内視鏡下に観察すると，食 道静脈瘤と異なり Red Color Sign (R-C sign)を認め ることは極めて稀である ${ }^{12)}$ 。食道静脈瘤における R-C signは，粘膜固有層や上皮直下に発達した静脈瘤分枝

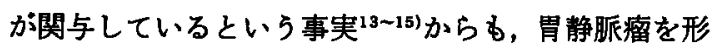
成する血管はすへて胃粘膜下層内に発達し, 粘膜固有 層内や上皮直下に発達することははとんどなく，あっ てす極めて稀であろらと推察される。 また胃静脈瘤出 血例を内視鏡的に検討した宇暒ら ${ }^{(2)}$ の報告によれば, 全例に胃静脈瘤上のびらんを認め, 食道静脈瘤に拉け る R·C sign とは異なり，胃静脈瘤出血には胃噴門部領 域の粘莫病変（びらん）が直接関与するとしている.

さて，従来明らかにされていなかった胃静脈瘤の支 配血行路につき，PTPにより検討したところ, 食道静 脈瘤は主として左胃静脈系に支配され，胃静脈瘤は後 胃静眽及び短胃静脈に優位に支配されることが明らか となった。

次に, PTPにより食道胃静脈瘤と胃堅短絡路につき
検討した。胃腎短絡路は胃噴門部付近及び左横隔膜下 面に発した左下横隔静脈が，下行して左副卧静脈と合 流して左腎静脈へ注ぐ経路が発達したものであ $\Xi^{7,8)}$. 左下横隔静脈は横隔膜直下で下大静脈へ注ぐ経 路む合せ持つが，門立症に際してこの経路が発達して 短絡路となることは稀である ${ }^{16,17)}$. 今回の検討によれ ば，食道静脈瘤単独群及び食道静脈瘤優位群では，胃 腎短絡路の頻度, 程度とすに低く, 胃静脈瘤が高度に なるにつれ胃腎短絡路の頻度，程度も高まり，巨大胃 腎短絡路を有する確率が高まる。

門脈圧と食道胃静脈瘤との関係について検討したと ころ, 胃静脈瘤を有しても食道静脈瘤が優位な群では, 食道静脈瘤単独群と門脈圧に差を認めなかった。しか 乙胃静脈瘤が発達するにつれ, 門脈圧は低下㑯向を示 し, 高度胃静脈瘤をすつ胃静脈瘤単独群では最す低い 門脈压を示した。これは胃静脈瘤が減圧のための有効 な短絡路つまり胃腎短絡路を有するからであると考え られた。これは胃静脈瘤を有する群の中です，胃腎短 絡路を有する群で有意に門脈圧が低値を示したことか ら明らかである。

次に, 上腸間膜静脈からの血流方向と食道胃静脈瘤 との関連につき検討した. その結果, 胃腎短絡路が高 度なほど脾静脈の血流は逆流することから, 高度胃静 脈瘤を有する群ほど脾静脈逆流がおこり, 胃静脈瘤単 独群では，7/8例 (88\%) に脾静脈逆流を認めた。これ は次に述へろ肝性脳症との関連において重要である。

肝性脳症は, 急性肝不全型, 末期進行型, 慢性反復 型と大別され, 慢性反復型は門脈大循環性脳症 (Portal-systemic encephalopathy) として特徽つけら れている18.19). すなわち, 消化管起原の含宔素物質が門 脈大循環短絡によって肝を迂回し直接大循環に流入 し, 中权神経系に作用して脳症をひき起こすと考えら れている.今回我々は，食道胃静脈瘤を有する230例の 検討対象のちち，12例にこの様な典型的な反復性肝性 脳症を認め，亏ち5 例 (41.7\%) と高率汇高度胃静脈 瘤を認めた，そこで，胃静脈瘤と反復性肝性脑症との 阅連につき検討したところ, 食道静脈瘤症例に比し， 高度胃静脈瘤症例 (胃静脈瘤単独例及び胃静脈瘤優位 例)で有意 $(\mathrm{p}<0.05)$ に脳症の頻度が高いことが明ら かとなった. この事実を，PTPによる血行動態でみる と,これら反復性肝性脳症を有した高度胃静脈瘤症例 5 例む，著明な胃腎短絡路を有していた，更に上腸間 膜静脈からの血行動態でみると，樶近 Takashi $5^{201}$ 報告した様にここれら 5 例はいずれる上腸間膜静脈血 
流が脾静脈を逆流し(らち 1 例は全血流の逆流), 胃静 脈瘤を介して胃堅短絡路に流出していたことが明らか となった。

以上，胃静脈瘤の血行動態及び臨床病態につき，主 として PTP 門脈X線像により明らかにしてきた。 と くに高度胃静脈瘾が，通常の食道静脈瘤とは全く異な る血行動態を有し，門脈王においても低値を示し，し ばしば反復性肝性脳症の原因となることを明らかにし た.この高度胃静脈瘤が特殊な血行動態を有すること が，胃静脈瘤が食道静脈瘤と異なり，粘膜固有層内ゃ 上皮直下に発達することが稀で，内視鏡的にる発赤所 見を呈しにくく，破綻出血が少ないことと関連してい ると著者らは推測する．また，近年食道静脈瘤に対す る非外科的治㞠法として, 内視鏡的硬化塞拴療法が厸 く普及しているが，胃静脈瘤は食道静脈瘤とは異なる 血行動態をとることを念頭におく必要がある，とくに 高度胃静脈瘤内に硬化剂を注入した際には，硬化剂が 直接胃腎短絡路に流出してしまうことを充分認識して おく必要があろら。

今回はPTP と内視鏡による検討であるため，それ それの評価には限界が存在するが，高度胃静脈瘤は特 殊な血行動態をとることが示された。

\section{結 論}

230例の食道胃静脈瘤症例に対し，食道胃内視鏡と PTPによる検討を行ない, 以下の結果を得た。

（1） $57 \%$ 症例に胃静脈瘤が存在した.

（2）食道静脈瘤は左胃静脈支配型が多く，胃静脈瘤 は高度になるにつれ, 短胃静脈, 後胃静脈支配型が増 学る。

（3）胃静脈瘤高度例では，下横隔静脈 $\rightarrow$ 左副腎静脈

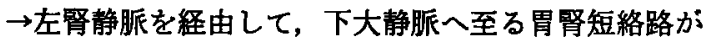
高率に存在する。

（4）胃腎短絡路を有する群は，有しない群に比し， 門脈王は有意泜低い。

（5）高度胃静脈瘤を有する群は，反復性肝性脳症を 起こす頻度が高い。

稿を終えるあたり，御指尊·御協力いただいた千葉大学第 一内科消化器研究室，及び関連施設の諸先生方に深謝いた します。
文城
1）井口 㴡爪誠：食道静脈瘤の natural his- tory. 消化器外科 $7: 525,1984$
2）長尾屏大，稲垣芳則：門脈圧六進症と胃出血. 外科

Mook 29: 178-187, 1983

3）日本門脈圧六進症研究会：食道静脈瘤内視鏡所見 記載基準. 肝臓 $21 ： 779,1980$

4）安元真武：胃静脈瘠の臨床的研究，100症例につい ての観察。日消会誌 $68: 721,1972$

5) Ohto $M$, Karasawa $E$, Tsuchiya $Y$, et al: Ultrasonically guided percutaneous contrast medium injection and aspiration biopsy using a real time puncture transducer. Radiology 136 : 171,1980

6) Okuda K, Kimura K, Takayasu K: Percutaneous transhepatic portography and sclerotherapy. Semin in Liver Dis $2: 57,1982$

7）福田 保, 橋本義雄：外科解剖 (4) 腹部。23-37, 196，医学書院，1978

8）平松京一：腹部血管の $X$ 線解剖図譜. 134-136, 196-206, 医学書院, 1982

9）山本貞博：食道静脈痹の手術一胃上部切除街．消 化器外科 $6: 831,1983$

10) Karr $S$, Wohl GT: Clinical importance of gastric varices. New Eng J M $263: 665,1960$

11) Evans JA, Delany F : Gastric varices. Radiology $60: 46,1953$

12）宇根晴康, 渡辺 净, 守田政彦, 他：胃噴門静脈瘪 出血例の内視鏡的検討. 日本消化器内視鏡学会総 会講演予報集 $25: 130,1983$

13）荒川正博，野田岳水，福田一典，他：食道静脈瘤の 臨床病理学的研究一食道壁内血管構築について。 日消誌 $80: 2339,1983$

14）熊谷義也, 幕内博康, 都築俊治, 他：食道静脈瘤の 内視鏡分類とその臨㕅的意義. 胃と腸 $11: 741$, 1976

15) Kegaries DL: The venous plexus of the esophagus. Its clinical significance. Surg Gynecol and Obst 58: 46, 1934

16）鶴丸昌彦：門脈王六進症に拈ける遠肝性副血行路 の湌討，日外会誌 $80 ： 424 ， 1979$

17) Rousselot LM, Moreno AH, Panke WF : Studies on portal hypertension. IV : The clinical and physiopathologic significance of selfestablished (nonsurgical) portal systemic venous shunt. Ann Surg 150 : 384, 1959

18) Sherlock S, Summerskill WHJ : Portalsystemic encephalopathy. Neurological complication of liver disease. Lancet $2: 453,1954$

19) Fischer JE: Hepatic coma in cirrhosis, portal 
hypertension, and following portacaval shunt. Its etiologies and the current status of its treatment. Arch Surg 108 : 325, 1974

20) Takashi M, Igarashi $M$, Hino $S$, et al : Portal hemodynamice in chronic portal-systemic encephalopathy. Angiographic study in seven cases. J Hepatol 1 : 467-476, 1985

\title{
Hemodynamics of gastric varices; study by percutaneous transhepatic portography
}

\author{
Kiyoshi Watanabe, Kunio Kimura, Shoichi Matsutani, \\ Masao OHTO and Kunio OKUDA*
}

Although bleeeding from gastric varices is said to be less frequent than that from esophageal varices, its hemodynamics have not been clarified yet. The purpose of this article was to analyze hemodynamics of gastric varices by means of percutaneous transhepatic portography which was carried out in 230 patients with gastroesophageal varices.

The incidence of gastric varices was endoscopically $57 \%$ of the 230 patients. In patients with remarkable gastric varices, the main variceal supply was the posterior gastric or short gastric vein, while the left gastric vein in those with esophageal varices. Compared to patients with esophageal varices, those with remarkable gastric varices more frequently had a gastro-renal shunt and portal systemic encephalopathy, and showed a lower portal venous pressure.

Thus, there are significant differences of hemodynamics and clinical features between gastric and esophageal varices.

* First Department of Medicine, Chiba University School of Medicine (Chiba) 